\title{
Nitrogen enrichment in macroalgae following mass coral mortality
}

\author{
Eleanor J. Vaughan ${ }^{1}$ - Shaun K. Wilson ${ }^{2,3}$ • Samantha J. Howlett ${ }^{1}$ • \\ Valeriano Parravicini $^{4,5}$ • Gareth J. Williams ${ }^{6}$. Nicholas A. J. Graham ${ }^{1}$
}

Received: 25 July 2020/Accepted: 11 March 2021/Published online: 12 April 2021

(C) The Author(s) 2021

\begin{abstract}
Scleractinian corals are engineers on coral reefs that provide both structural complexity as habitat and sustenance for other reef-associated organisms via the release of organic and inorganic matter. However, coral reefs are facing multiple pressures from climate change and other stressors, which can result in mass coral bleaching and mortality events. Mass mortality of corals results in enhanced release of organic matter, which can cause significant alterations to reef biochemical and recycling processes. There is little known about how long these nutrients are retained within the system, for instance, within the tissues of other benthic organisms. We investigated changes in nitrogen isotopic signatures $\left(\delta^{15} \mathrm{~N}\right)$ of macroalgal tissues (a) $\sim 1$ year after a bleaching event in the Seychelles and (b) $\sim 3$ months after the peak of a bleaching
\end{abstract}

Topic Editor Andrew Hoey

Supplementary Information The online version contains supplementary material available at https://doi.org/10.1007/s00338021-02079-w.

Eleanor J. Vaughan

e.vaughan@lancaster.ac.uk

1 Lancaster Environment Centre, Lancaster University, Lancaster LA1 4YQ, UK

2 Department of Biodiversity, Conservation and Attractions, Kensington, Perth, WA 6151, Australia

3 Oceans Institute, University of Western Australia, Crawley, WA 6009, Australia

4 PSL Université Paris, USR 3278 CRIOBE - EPHE-UPVDCNRS, Université de Perpignan, 66860 Perpignan, France

5 Laboratoire D'Excellence "CORAIL”, Perpignan, France

6 School of Ocean Sciences, Bangor University, Menai Bridge, Anglesey LL59 5AB, UK event in Mo'orea, French Polynesia. In the Seychelles, there was a strong association between absolute loss in both total coral cover and branching coral cover and absolute increase in macroalgal $\delta^{15} \mathrm{~N}$ between 2014 and 2017 (adjusted $r^{2}=0.79, p=0.004$ and adjusted $r^{2}=0.86$, $p=0.002$, respectively). In Mo'orea, a short-term transplant experiment found a significant increase in $\delta^{15} \mathrm{~N}$ in Sargassum mangarevense after specimens were deployed on a reef with high coral mortality for $\sim 3$ weeks $(p<0.05)$. We suggest that coral-derived nutrients can be retained within reef nutrient cycles, and that this can affect other reef-associated organisms over both short- and longterm periods, especially opportunistic species such as macroalgae. These species could therefore proliferate on reefs that have experienced mass mortality events, because they have been provided with both space and nutrient subsidies by the death and decay of corals.

Keywords Climate change - Macroalgal bioindicators . Coral bleaching - Stable isotopes - Biogeochemical cycles . Coral reef ecology

\section{Introduction}

Tropical coral reefs are highly productive ecosystems, but as they are typically surrounded by oligotrophic waters, they require constant recycling and retention of waterborne nutrients and organic matter (Galloway et al. 2004). There are a wide range of physical and biological processes on coral reefs which can retain these essential energetic resources within local biogeochemical cycles for extended periods of time. Thus, these processes can sustain rapid rates of biological activity such as primary productivity, as well as many other key ecosystem functions (Wyatt et al. 
2013). For instance, coral-derived particulate organic matter (POM) in the form of mucus can act as an energy carrier and particle trap, so these nutrients may be recycled by benthic and planktonic communities over longer timescales (Ferrier-Pagès et al. 1998; Wild et al. 2004a, b). However, even in a coral-dominated ecosystem, they are not the only natural, or autochthonous, source of bioavailable nutrients (Davey et al. 2008; Wyatt et al. 2013; Tanaka and Nakajima 2018). Microbes, for instance, are capable of nitrogen fixation (Moulton et al. 2016), and other primary producers, such as phytoplankton and macroalgae, readily take up and store nutrients and dissolved organic matter (DOM) in their tissues (Fong et al. 1994). This DOM is then recycled either through tissue breakdown or through consumption by higher trophic level organisms such as herbivorous fishes, which in turn recycle significant amounts of nutrients through excretion (Burkepile et al. 2013).

Healthy coral reefs typically persist in low nutrient waters, although nutrient pulses can disrupt the balance of natural biogeochemical dynamics jeopardising reef health. Disturbances such as marine heat waves that cause coral bleaching have a direct negative impact on corals, but can also have indirect consequences for reefs by altering nutrient dynamics (D'Angelo and Wiedenmann 2014). Branching scleractinian corals are often dominant on a reef, providing structural complexity and micro-habitats for a variety of reef-associated organisms, but they are also particularly vulnerable to heat stress (Hughes et al. 2019). The loss of these vital foundation species therefore has huge implications for the entire ecosystem (Graham et al. 2015; Wilson et al. 2019). Where coral bleaching causes extensive mortality, the metabolic exchange between corals and associated organisms on a reef is reduced, along with the capacity of corals to trap organic matter. This can subsequently trigger the dysfunction of major biogeochemical processes (Glynn 1993; Wild et al. 2011).

There are few studies assessing how climate-derived disturbances affect mucus release by live corals, and associated processes. Davey et al. (2008) found that in the weeks that follow coral bleaching, a 30 -fold higher production of new nitrogen occurred on coral reefs compared to those that did not experience bleaching. Such nitrogen productivity has also been shown in an experimental setting (Niggl et al. 2009). While release rates of mucusderived POM from corals increase during the early stages of bleaching, providing a burst of nutrients to coral reefs (Coffroth 1990), these rates can decrease after the initial bleaching response (Fitt et al. 2009; Wooldridge 2009). If corals recover from bleaching, which can take many weeks to occur (Gates 1990), there may only be short- to mediumterm effects on biogeochemical processes. However, if corals die, the subsequent mass release of coral tissue into reef environments may also alter biogeochemical processes, and over longer time scales. In addition, colonisation of the exposed coral skeleton by microbial biofilms, turf algae, macroalgae, sponges, cyanobacteria or other invertebrates may not only reduce coral recruitment success, but can also change biogeochemical processes such as nitrogen fixation (Diaz-Pulido and McCook 2002; Davey et al. 2008; Haas et al. 2010).

In order to identify changes in nutrient regimes due to mass coral mortality, nitrogen stable isotopes $\left(\delta^{15} \mathrm{~N}\right)$ and nitrogen content $(\% \mathrm{~N})$ can be analysed from macroalgal tissues to capture temporally-extensive records of nutrient loads (Costanzo et al. 2001). Stable isotopes of nitrogen have been used in nutrient studies for several decades, helping to identify the origins of nitrogen (Heaton 1986; Kolasinski et al. 2011). In addition, certain types of marine algae are commonly used in biomonitoring studies due to their widespread distribution and responsiveness to bioavailable pollutants. Sargassum, for example, is a genus used worldwide as it has been found to be responsive to nutrient enrichment (Schaffelke and Klumpp 1998; Schaffelke 2002; García-Seoane et al. 2018). However, marine algae are not the only functional group that can be used to measure isotopic signatures as a proxy of nutrient regimes on reefs. Organisms at higher trophic levels also assimilate nutrients from lower trophic levels, resulting in increasing isotopic enrichment up the food chain (Bierwagen et al. 2018). For instance, corals are at a higher trophic level than primary producers such as macroalgae, and thus have enriched isotopic signatures (Graham et al. 2018). As corals release organic matter into the water column after the death and subsequent decay of tissue following marine heatwave-driven mortality events (Leggat et al. 2019), opportunistic benthic species such as macroalgae may capitalise on this new nutrient source, assimilate it into tissues for growth and storage, and consequently become more enriched (Pawlik et al. 2016).

In the current study, the temporal effect of coral mass mortality on macroalgal stable isotopic signatures is investigated in two different coral reef systems, over two different time periods. As such, it offers new understanding on whether macroalgae can indicate longer-term effects of coral mortality events on reef nutrient dynamics and biogeochemical cycles. Specifically this study assesses: (1) changes in Sargassum sp. nutrient signatures over three years in the inner Seychelles Islands, western Indian Ocean, spanning a mass coral bleaching event, and (2) shorter-term changes in Sargassum mangarevense nutrient signatures $\sim 3$ months after the peak of a severe bleaching event in Mo'orea, French Polynesia, using an in-situ three-week transplant experiment. 


\section{Methods}

\section{Study Site 1: Seychelles}

The inner Seychelles islands experienced two severe coral bleaching events, in 1998 and 2016. In 1998, coral cover dropped by $90 \%$, and though hard coral cover steadily recovered on some study sites (average coral cover of $27 \%$ by 2014) (Graham et al. 2015), another global bleaching event in 2016 (Hughes et al. 2018) led to live coral cover declining by $70 \%$ on these same sites (Wilson et al. 2019). Around the Inner Seychelles, heat stress reached $4{ }^{\circ} \mathrm{C}$ weeks in January 2016, rapidly increased in April and peaked at $11.4{ }^{\circ} \mathrm{C}$ weeks in May (Wilson et al. 2019; http:// coralreefwatch.noaa.gov/vs/index.php).

Eighteen reefs were surveyed in April 2014, before the mass bleaching event caused extensive coral mortality in 2016 and again in April 2017, a year after the event occurred (Wilson et al. 2019). These reefs form part of a 25-year coral reef monitoring survey around the inner Seychelles, with roughly half the reefs having been defined as "recovering" from a previous mass bleaching event in 1998, and the other half as transitioning to a "regimeshifted" macroalgae-dominated state (Graham et al. 2015). Eight replicate $7-\mathrm{m}$ radius point counts were surveyed along the reef slope on each reef for both survey years. Within each point count area, the percent cover of benthic categories including live hard coral, soft coral, macroalgae, sand, rubble and rock was quantified using 10-m-long lineintercept transects (Wilson et al. 2019).

The objectives of this component of the study were to assess the relationship between changes in percent cover of corals between the study years of 2014 and 2017 with differences in $\delta^{15} \mathrm{~N}$ and $\% \mathrm{~N}$ signatures in tissues of Sargassum sp. that were collected from the same sites during the same surveys. Low availability of macroalgae at some reefs meant that macroalgae for stable isotope analyses were not collected from all reefs in both years. A minimum of four replicate Sargassum sp. samples were collected from each of the seven "coral mortality" reefs (a subset of the previously termed "recovery reefs", named as such following the impacts of the 2016 bleaching event) and from the six "regime-shifted" reefs in both 2014 and 2017.

\section{Study Site 2: Mo'orea}

Mo'orea, an island which is part of the Society Archipelago in French Polynesia, has demonstrated rapid coral recovery from previous disturbances (Vercelloni et al. 2019; Hédouin et al. 2020). For example, following an outbreak of Acanthaster spp. from 2006 to 2009 and a cyclone in 2010 , mean coral cover on the outer reefs was reduced to
$2 \%$ at $10 \mathrm{~m}$ depth from a high of $39 \%$ in 2005 , before recovering to $27 \%$ in just four years. The branching coral genus Pocillopora spp. was found to be a significant driver in that recovery, as it made up 53\% of the re-established coral community (18\% cover) (Tsounis and Edmunds 2016). There were no recorded episodes of abnormally high sea surface temperature (SST) in 1998 in Mo'orea, but it was impacted by the global coral bleaching event in 2016, with heat-sensitive branching corals being the worst affected (Hughes et al. 2019). Donovan et al. (2020) reported that $37 \%$ of Acropora and $28 \%$ of Pocillopora colonies exhibited bleaching across all sites, with up to $100 \%$ bleaching of Acropora on north shore sites. Coral mortality was rare $(\sim 1 \%)$, as heat stress did not exceed $1.1{ }^{\circ} \mathrm{C}$ weeks (Hédouin et al. 2020).

Annual surveys of 13 marine areas around Mo'orea were established in 2004 (Service National d'Observation CORAIL). For the purpose of this study, data for the reef slope at the four areas along the north coast of the island, where bleaching was highest and our study site was located, were used (Suppl Fig. 1). This includes the site Tiahura which is closest to our study site. The benthic cover of each sample area was quantified at a similar depth to the transplant site $(\sim 10 \mathrm{~m})$ using 3 replicate non-permanent $25 \mathrm{~m}$ transects (Horta e Costa et al. 2016). The percentage cover of benthic components was sampled every $50 \mathrm{~cm}$ using the point intercept transect (PIT) method. Macroalgae were categorised as all the non-coralline algae of large enough size to identify with the naked eye.

Sea surface temperature (SST) was measured hourly using an SBE-56 sensor (Sea Bird Scientific) on the Tiahura forereef at $3 \mathrm{~m}$ depth from 1998 to 2005 . The time series was interrupted for 5 years before being collected continuously again from 2010 . In order to characterise the temperature trend in 2019, relative to that of other years, we calculated weekly means for 2019 and compared this with the average temperature time series and $95 \%$ confidence intervals for the entire period. In addition, following Donovan et al. (2020), we calculated cumulative heat stress (in ${ }^{\circ} \mathrm{C}$ weeks) as a 12 -wk running sum for all temperatures exceeding $29^{\circ} \mathrm{C}$, a threshold that is considered a good predictor of bleaching in Mo'orea based on previous studies (Pratchett et al. 2013; Donovan et al. 2020; Hédouin et al. 2020). The maximum water temperature during 2019 exceeded $29{ }^{\circ} \mathrm{C}$ in March and peaked at $30{ }^{\circ} \mathrm{C}$ in April. Patterns of cumulative heat stress peaked at $\sim 6{ }^{\circ} \mathrm{C}$ weeks. As the duration of heat stress was much longer in 2019 than in the previous bleaching event (Donovan et al. 2020; Hédouin et al. 2020), the extent of coral mortality was much higher (Suppl Fig. 2).

Samples of Sargassum mangarevense $(n=10)$ were collected from Papetoai lagoon, a low-nutrient reef in the northwest region of Mo'orea on 6th July 2019 
(Suppl Fig. 1). These waters were found to typically have low $\delta^{15} \mathrm{~N}$ and $\% \mathrm{~N}$ values, shown in nutrient heat maps in Leichter et al. (2013) and Donovan et al. (2020). Specimens were placed in shaded coolers filled with seawater before they were transported back to the CRIOBE research station, Mo'orea. After all visible, larger epiphytes were carefully removed from the fronds using a scalpel; initial tissue samples were taken and frozen at $-20{ }^{\circ} \mathrm{C}$ for later stable isotopic analyses. Algal specimens were then placed in pre-transplant holding tanks for seven days, with water changes every 2 days. Water changes in the tanks involved surface water collected from the forereef, as it was found to typically be low in $\delta^{15} \mathrm{~N}(<3.0 \%$, Lin and Fong 2008; Donovan et al. 2020). This was done to ensure that internal nutrient stores in $S$. mangarevense were depleted before specimens were transplanted on the forereef where there were high levels of coral mortality. Following this 7-day acclimation period, further tissue samples were taken for stable isotopic analyses. For the in situ macroalgal bioassay, a cage was made out of chicken-wire mesh and attached to a cinder block that was already placed on the forereef at $\sim 12 \mathrm{~m}$ depth. At the time of the transplant experiment in July 2019, while some corals were still bleached, $\sim 40 \%$ had already died (S.J.H., 2020, pers. obs.). It was not possible to have a control bioassay, due to restrictions on deploying additional cinder blocks and the lack of non-bleached reefs at that time. The ten macroalgal specimens were deployed on the reef for $\sim 3$ weeks from 15th July to 4th August 2019 before they were collected and returned to CRIOBE. Final tissue samples were taken and frozen before stable isotopic analyses were performed.

\section{Stable isotopic analyses}

All frozen samples from both studies were defrosted, rinsed thoroughly with fresh or distilled water, and placed in a drying oven for $48 \mathrm{~h}$ at $60{ }^{\circ} \mathrm{C}$. Once dried, samples were each ground into a fine powder using a ball mill and stored in individual airtight containers. All dried samples were weighed, alongside the relevant standards, for stable isotopic analyses. Samples were then run on an IsoPrime Dual Analyser to determine signatures of stable isotopes and elemental content. The stable isotopic $\left(\delta^{15} \mathrm{~N}\right)$ and elemental analyses $(\% \mathrm{~N})$ for both the 2017 samples from the Seychelles study and the 2019 Mo'orea samples were run on an Isoprime100 Isotope Ratio Mass Spectrometer (IRMS) linked to an Elementar VARIO MICROcube Elemental Analyser at Lancaster Environment Centre, Lancaster University. The samples collected in 2014 from the Seychelles were analysed using a Costech Elemental Analyser fitted with a zero-blank auto-sampler at James Cook University's Advanced Analytical Centre, Cairns. Analyses from both years were standardised using internal reference materials calibrated to international standards.

\section{Statistical analyses}

For the Seychelles data, four separate two-way analysis of variance (ANOVAs) were used to assess the effect of time period (two levels: 2014 and 2017), reef state (two levels: coral mortality and regime shift) and their interaction on (a) total coral cover, (b) branching coral cover, (c), $\delta^{15} \mathrm{~N}$ and d) $\% \mathrm{~N}$ across all 13 reefs where Sargassum were consistently collected. Based on this analysis and subsequent post hoc Tukey tests, we found that predominant changes in these response variables were observed on "coral mortality" reefs, with little response on "regimeshifted" reefs. We therefore include the seven reefs with high levels of coral mortality to investigate the relationship between changes in nutrient signatures against a) absolute and b) branching coral cover loss, using linear regression models. This decision was further supported by coral cover changes on "regime-shifted" reefs, where starting absolute values in 2014 were already very low at $6.69 \pm 1.8 \%$ before dropping by $\sim 5 \%$ in 2017 , and macroalgal cover was very high in both years. Therefore, any influence of coral cover on nutrient signatures in the system would be negligible (Suppl Fig. 3; Wilson et al. 2019).

For the Mo'orea data, differences between (a) average $\delta^{15} \mathrm{~N}$ and (b) $\% \mathrm{~N}$ signatures in the Sargassum specimens in the three treatments (initial, pre-transplanted and posttransplanted) from the transplant experiment were analysed using a repeated measures ANOVA. Repeated measures were incorporated into this ANOVA as tissue samples were taken from the same experimental specimens placed under the three different treatments. A time series analysis was conducted to compare the average mean monthly SST in 2019, relative to SST in previous years. Normality of data was assessed visually, and homogeneity of variance for all ANOVAs conducted for both studies was assumed with a Levene's test. All statistical analyses were conducted in $\mathrm{R}$ (R-Core-Team 2018), and the time series analyses for Mo'orea were performed using "zoo" and "xts" packages to produce Supplementary Fig. 2 (Zeileis and Grothendieck. 2005; Ryan and Ulrich 2020).

\section{Results}

\section{Seychelles}

There was a significant effect of year, reef state and interaction on total coral cover across the thirteen reefs (interaction: $F_{1,204}=37.3, p<0.0001$ ). The post hoc Tukey test revealed that there was no significant difference 
a

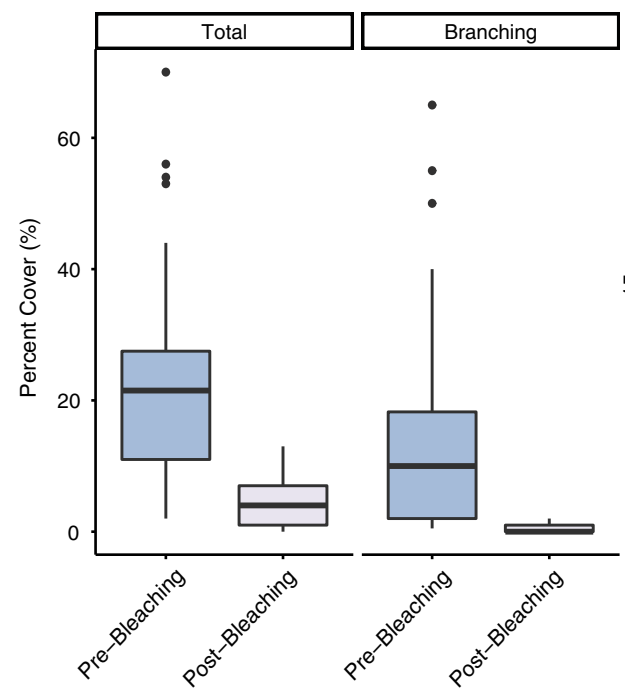

b

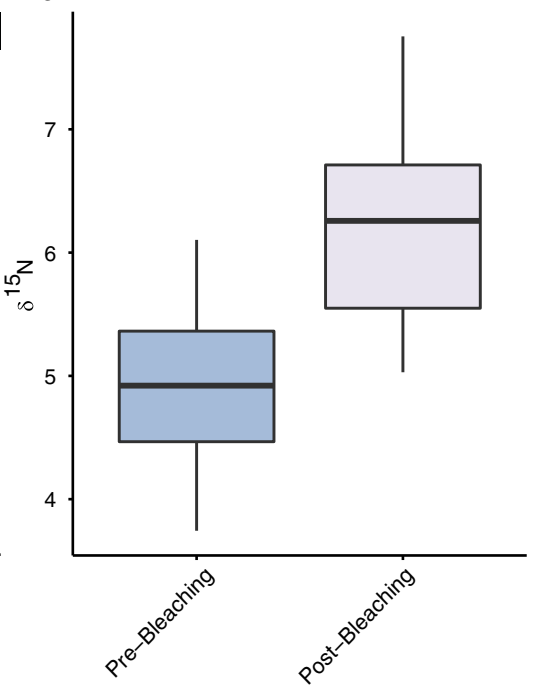

c

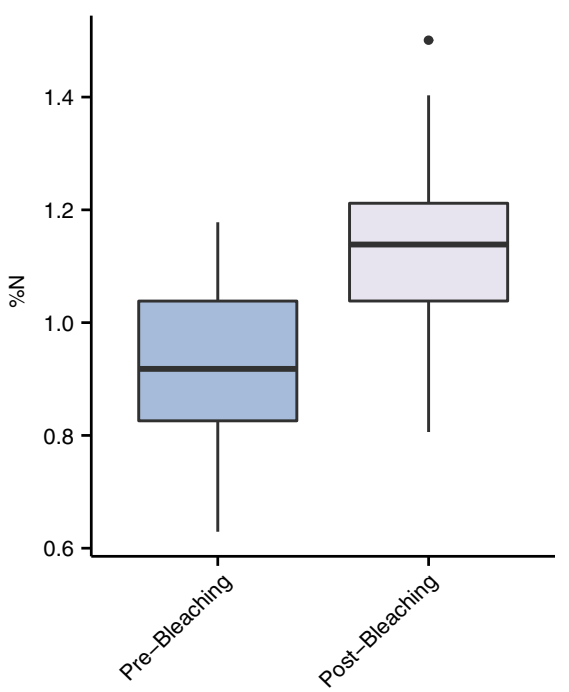

Fig. 1 Box and whisker plots of the median a total and branching coral cover in both pre-bleaching and post-bleaching years (2014 and 2017 , respectively) on "coral mortality" reefs $(n=7)$, b the average $\delta^{15} \mathrm{~N}$ signatures in Sargassum sp. tissues in both years, and c the

between the pre- and post-bleaching years for the "regimeshifted" reefs ( $p=0.32$; Suppl. Fig. 2). In contrast, the seven "coral mortality" reefs declined significantly from $27.0 \pm 1.5$ to $8.01 \pm 0.5 \%$ between 2014 and 2017 ( $p<0.0001$; Fig. 1a). This was mainly due to a loss in branching coral cover on these reefs from $16.0 \pm 1.5$ to $0.30 \pm 0.05 \% \quad(p<0.0001$; Fig. 1a). Percent cover of massive corals remained similar between 2014 and 2017 on "coral mortality" reefs, whereas table coral cover declined from $1.27 \%$ to $0 \%$. There was also a $0.8 \%$ increase in total macroalgal cover on the seven study reefs between the years.

The $\delta^{15} \mathrm{~N}$ signature in Sargassum tissues differed significantly between 2014 and 2017 across all thirteen reefs (interaction between year and reef state, $F_{1,124}=11.4$, $p=0.001$ ), but only showed a significant difference for the seven "coral mortality" reefs between survey years ( $p<0.0001$, Fig. $1 b ; p=0.15$ for regime-shifted reefs). Similarly, \%N in Sargassum tissues was higher in samples collected from "coral morality" reefs in 2017 than in 2014 $(p<0.0001$, Fig. 1c; significant interaction between year and state $F_{1,124}=5.0, p=0.03$ ), although there was no temporal difference in $\mathrm{N}$ content in samples collected from "regimeshifted" reefs $(p=0.20)$. For the seven "coral mortality" reefs selected for the purpose of this study, there was a significant positive relationship between increase in $\delta^{15} \mathrm{~N}$ in Sargassum tissue and (a) loss of total coral (adjusted $r^{2}=0.79 ; p=0.004$; Fig. 2) and (b) branching coral cover (adjusted $r^{2}=0.86$; $p=0.002$ ). There was no significant relationship between changes in $\% \mathrm{~N}$ and total coral cover $\left(r^{2}=0.04 ; p=0.67\right)$ or branching coral cover $\left(r^{2}=0.04 ; p=0.66\right)$. average percent $\mathrm{N}(\% \mathrm{~N})$ in both years. The pale blue boxes represent the pre-bleaching year and pale pink boxes represent the postbleaching year, both showing the third quartile (Q3) and first quartile (Q1) range of the data, the whiskers (95\% quartile) and data outliers

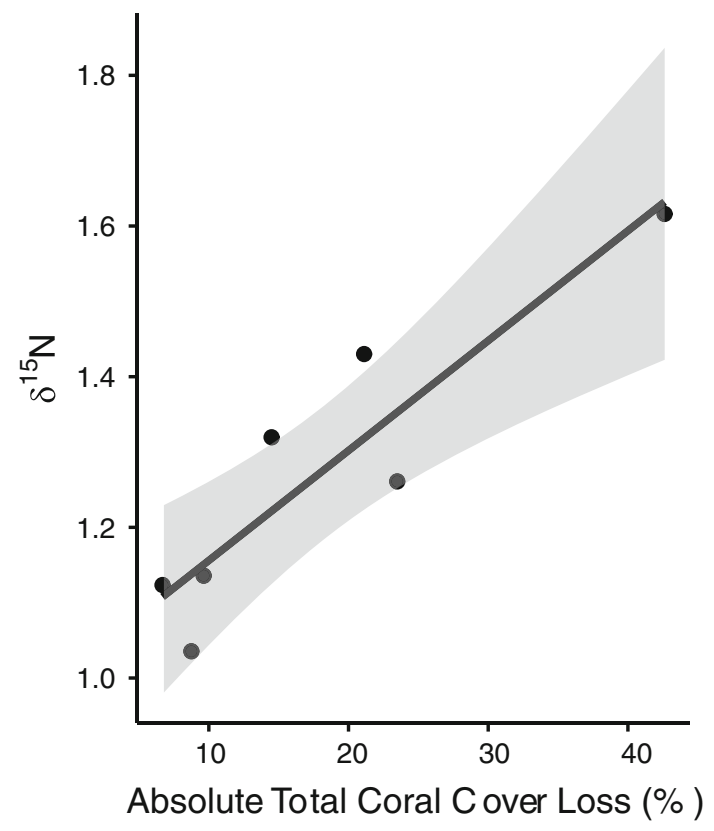

Fig. 2 Change in absolute total coral cover and the corresponding changes in $\delta^{15} \mathrm{~N}$ in Sargassum tissues across seven coral mortality reefs in the Seychelles between 2014 and 2017. The regression lines and confidence intervals were obtained using linear regression coefficient of determination $\left(r^{2}\right) ; 95 \%$ confidence intervals

\section{Mo'orea}

Before the bleaching event peaked in April 2019 (Suppl Fig. 2), the benthic cover survey conducted across the outer slopes of the four northern sites of Mo'orea in March 2019 showed an average of $73.7 \pm 2.8 \%$ live coral cover, 
with a significant decline to an average of $36.2 \pm 2.9 \%$ in 2020 , a year after the event $(p<0.0001$; Mean \pm SE). The closest site to the transplant experiment, Tiahura, had $73.3 \pm 5.5 \%$ and $36.0 \pm 2.0 \%$ in live coral cover in 2019 and 2020, respectively. The high coral cover across the four sites in 2019 was primarily due to the abundance of branching coral Pocillopora on the forereefs in Mo'orea (Tsounis and Edmunds 2016). For instance, at Tiahura, there was $60.7 \pm 5.7 \%$ cover of Pocillopora and an average of $55.5 \pm 3.3 \%$ cover across the four sites in 2019 . When the survey was repeated in March 2020, there was a significant decrease in Pocillopora to $24.5 \pm 1.7 \%$ across all four sites $(p<0.0001)$, and a similar pattern was shown at Tiahura $(p<0.0001)$. Other than this predominant branching coral, no significant differences were found between the years for the other reef-associated organisms, including other coral genera.

In the short-term transplant experiment shortly after the peak of the bleaching event in Mo'orea, treatment had a significant effect on macroalgal $\delta^{15} \mathrm{~N}$ signatures (repeatedmeasures ANOVA: $F_{2,27}=31.71, p<0.0001$; Fig. 3). Post hoc tests indicated that there were significant differences in $\delta^{15} \mathrm{~N}$ between all three treatments (initial, pre-transplant and post-transplant, $n=10$ ), which suggested that $\delta^{15} \mathrm{~N}$ declined in the pre-transplant holding tanks, and then increased substantially on the transplant reef (initial and pre-transplant: $p=0.003$; initial and post-transplant: $p<0.0001$; pretransplant and post-transplant: $p<0.0001)$. However, there was no significant effect of treatment on macroalgal $\% \mathrm{~N}$ (repeated-measures ANOVA: $F_{2,23}=0.6, p=0.58$; Suppl Fig. 4). Although it was not possible to include either control sites or reefs with varying levels of bleaching due to permit restrictions, the benthic data show that the extent of coral mortality across the outer slopes on the northern region of Mo'orea was quite similar.

\section{Discussion}

The current study suggests that mass coral mortality events can be detected through nitrogen isotopic signatures in macroalgal tissues, a proxy for nutrient sources, up to a year after a severe bleaching event. Although the exact source of the enrichment could not be traced in this study, a significant increase in $\delta^{15} \mathrm{~N}$ was shown in both reef systems over different timescales after two separate coral mortality events. For instance, in the Seychelles, there was a strong positive correlation between a decline in total coral cover and an increase in $\delta^{15} \mathrm{~N}$. This suggested that the $\mathrm{N}$ present in algal tissues could be coral-derived. These findings may help improve understanding of how mass disturbances such as coral bleaching impact multiple ecosystem processes on climate-impacted reefs. For instance, the loss of live coral

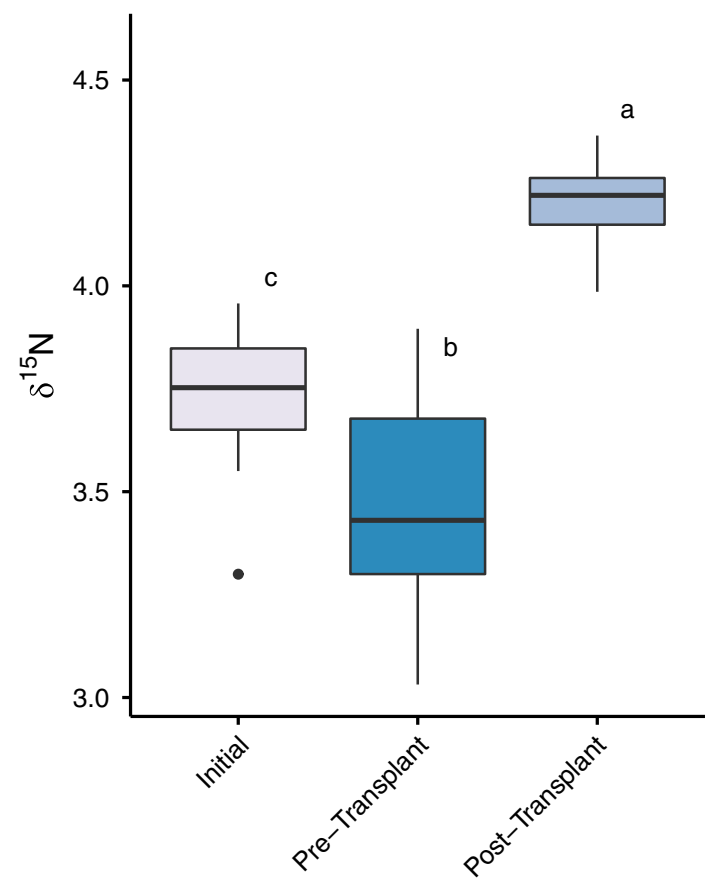

Fig. 3 Box and whisker plots of the median $\delta^{15} \mathrm{~N}$ in Sargassum mangarevense tissue across three treatments from a short-term transplant experiment, showing the third quartile (Q3) and first quartile (Q1) range of the data, the whiskers (95\% quartile) and data outliers. Connecting letters indicate significant differences between treatments. Stable isotopic signatures were measured in subset samples of the same specimens that were collected from a lownutrient reef (initial), placed in laboratory aquaria to deplete internal nutrient stores for $\sim 7$ days (pre-transplant), before they were deployed on the bleached reef for 3 weeks (post-transplant) $(n=10)$

cover, especially branching corals, provides a large amount of new substrate for opportunistic species such as macroalgae and other primary producers to colonise and prevent coral recovery, and may also provide an additional source of nutrients which become locked in the system. Consequently, this could enhance macroalgal proliferation on this colonised space, reinforcing alternative regimes.

The isotopic signature of fleshy macroalgae changed significantly over both short and long timeframes following bleaching events on two different reef systems. The positive relationship between $\delta^{15} \mathrm{~N}$ and the declines in coral cover suggest that nutrients from dead and decaying corals have contributed to this change of isotopic signatures in macroalgae. While this might be an important natural source of nutrients (Coffroth 1990; Brown and Bythell 2005; Bythell and Wild 2011), any substantial increase could affect or disrupt natural metabolic exchanges between corals and other organisms, not only with their endosymbiotic zooxanthellae, but with sponge, seaweed and microbial communities (de Goeij et al. 2013; Rix et al. 2016, 2017; Pawlik et al. 2016; Mumby and Steneck, 2018; Leggat et al. 2019). Much of the literature focuses on the 
mucus released from live corals and how it is recycled within the system (Davey et al. 2008; Naumann et al. 2009; Wild et al. 2004a, b, 2010, 2011), as well as the short term effects of changes in organic matter release after a bleaching event (Niggl et al. 2009; Wooldridge, 2009). Other work such as Radice et al. (2020) supports this by showing that isotopic signatures of particulate organic nitrogen in the water column decreased 8 months after a bleaching event. However, there is still little understanding of changes in reef biogeochemical cycles.

Excess nutrients are one of the key factors that can drive a bleached reef towards a regime shift (Graham et al. 2015). If the increased release of organic matter through mass coral mortality provides more nutrients to opportunistic species, this may encourage fast-growing macroalgae to proliferate on the exposed coral skeletons. This negative feedback loop can inhibit coral recovery and foster regime shifts to macroalgal-dominated states (DiazPulido and McCook 2002; Haas et al. 2010; Wild et al. 2011). For instance, the lack of available substrata may reduce the ability for any coral larvae to colonise this space and repopulate reefs, whilst increases in algal-derived DOM and POM can subsequently increase pathogenic microbial activity through what has been termed the DDAM positive feedback loop (dissolved organic carbon, disease, algae, microorganisms) (Haas et al. 2016). Macroalgae release labile organic matter which benefit pathogenic microbes and together they create unfavourable conditions for corals. For example, they collectively disrupt the function of the coral holobiont, thereby exacerbating death of coral recruits, and maintaining competitive dominance in algae (Wild et al. 2010; Barott and Rohwer 2012; Pawlik et al. 2016; Mumby and Steneck 2018).

While mass mortality has the potential to release a substantial source of new nutrients, this type of organic matter is still considered to be internal, or autochthonous (Briand et al. 2015). Excessive nutrient enrichment from external anthropogenic nutrient loads, particularly certain types of nitrogen such as nitrates found in coastal runoff, can further exacerbate changes in biogeochemical cycles on reefs (Burkepile et al. 2020; Donovan et al. 2020). This could accelerate the proliferation of macroalgae and other opportunistic organisms, and further decrease the chance of scleractinian corals re-establishing themselves. In addition, declines in water quality can develop and cause the formation of algal blooms (Fabricius 2005; Tanaka et al. 2010).

Fleshy macroalgae are important indicators of changes in nutrient cycles because the bioavailable nutrients which are taken up from the water column and assimilated into their tissues can be easily measured over both short and long periods of time (Costanzo et al. 2001). Macroalgae have been used as proxies to study the effects of nutrient enrichment in both laboratory and in situ experiments, but these mostly tend to be for investigating anthropogenic sources, such as from coastal run-off (Fong et al. 1994; García-Seoane et al. 2018; Burkepile et al. 2020) and less commonly for natural nutrient inputs, such as seabird guano, deep-water upwelling events or coral-derived organic matter (Schaffelke, 2002; Graham et al. 2018; Williams et al. 2018).

The kind of nutrient signature used as a bioindicator is also an important factor to consider. Lin and Fong (2008) found $\delta^{15} \mathrm{~N}$ to be a more sensitive indicator to changes in nutrients in transplanted macroalgae than $\% \mathrm{~N}$. Nitrogen content is typically diluted during rapid growth of specimens, suggesting that nutrients are only stored in macroalgal tissues over the long term when nutrient supply exceeds growth rate, as they first must assimilate excess nitrogen into growth. This likely explains why we found no patterns in $\% \mathrm{~N}$ in either the Seychelles regression analysis, or the Mo'orea transplant experiment.

Although the duration of transplant experiments in the literature varies considerably, from hours to $\sim 1$ year, García-Seoane et al. (2018) recommended an exposure time of $<1$ month, as the uptake kinetics of algal transplants can vary based on the species used or local environmental conditions. The current study suggests that these changes in nutrients may be detected in Sargassum tissues up to 12 months after an event, implying that nutrients have been trapped and retained in the system for at least a year. It is also known that Sargassum undergoes major seasonal fluctuations in production and biomass that may supplement adjoining ecosystems within the broader seascape (Fulton et al. 2019). This study supports previous literature, suggesting that macroalgae can easily be deployed in target areas to investigate changes in nutrient loads (Costanzo et al. 2001; García-Seoane et al. 2018), but also applies this common technique to capturing energetic resources. Therefore, macroalgal assays have the potential to provide insight into changes in nutrient sources from both natural and anthropogenic events, such as widespread coral bleaching.

There are a number of potential sources of nitrogen that could have influenced our results other than coral-derived nutrients. A strong nutrient gradient from the land-end of Opunohu Bay in Mo'orea to its ocean-end (Lin and Fong 2008) suggests that the nutrient enrichment from the shrimp farm effluent entering the bottom of the bay was unlikely to affect the isotopic signatures of our specimens. However, storms and heavy rainfall can influence both the spatial extent of run-off and nutrient uptake in reef macroalgae (Clausing and Fong 2016; Adam et al. 2021). Local upwelling could have provided nutrients and influenced our results, but Lin and Fong (2008) suggest that the $\delta^{15} \mathrm{~N}$ of tropical ocean seawater is typically $\sim 3 \%$, which 
is lower than the signatures found in both the post-transplant and pre-transplant tissue samples. In addition, no Sargassum specimens were found at the depth where the bleaching occurred in Mo'orea $(\sim 12 \mathrm{~m})$, so specimens had to be taken from the nearby nutrient-limited lagoon $(\sim 1 \mathrm{~m})$. Although this lagoon typically has low nutrient levels (Donovan et al. 2020) and the algal specimens collected from there had low tissue nutrient history, some bleaching was observed in the lagoon at the time of collection, but not in the specific area where the specimens were collected. Even if some coral-derived nutrients were captured by the initial specimens, we accounted for this by depleting tissue nutrient stores in the holding tanks. This resulted in a significant decline in $\delta^{15} \mathrm{~N}$, followed by a significantly higher signature in the post-treatment algae after they were transplanted at the site where extensive coral bleaching and mortality had occurred. Other factors such as light intensity can also affect algal condition and isotopic signatures (Marconi et al. 2011; García-Seoane et al. 2018), so may have also influenced results in Mo'orea.

Future research could build on this study, and on other studies in the literature (García-Seoane et al. 2018) by applying the above methods to test the degree of influence of coral-derived organic matter on macroalgal nutrient signatures, relative to anthropogenic sources, either in laboratory- or field-based experiments. For instance, macroalgal bioassays could be deployed on bleached reefs with low levels of coastal run-off, such as those in other regions around Mo'orea, and compared to those with significantly higher levels, to test if these effects are synergistic. Clearly, assessment of macroalgal isotope signatures across different nutrient loads and levels of coral mortality is required to fully understand nutrient sources before attribution of nitrogen enrichment in macroalgae to nutrients released from dead and decaying corals can be definitively determined.

While this study compared the $\delta^{15} \mathrm{~N}$ signatures in tissues of Sargassum from pre- and post-bleaching years in the Seychelles, no macroalgal samples were collected during the bleaching and the subsequent mortality event in 2016 itself, so it was not possible to compare the stable isotopic results when this mass tissue release was occurring. The short-term experiment in Mo'orea was conducted in part to understand these shorter-term dynamics and to further support these findings. Though the results from the two different reef systems are not directly comparable, this study suggests that macroalgal tissue $\delta^{15} \mathrm{~N}$ signatures can be affected by mass morality events. However, as the current study only implies that the mass release of dead coral tissue enriched the macroalgal $\delta^{15} \mathrm{~N}$ signatures, future research could expand on this work by determining the exact source(s) of enrichment (Briand et al. 2015). For instance, enriched stable isotope tracers $\left({ }^{15} \mathrm{~N}\right.$ and $\left.{ }^{13} \mathrm{C}\right)$ (Naumann et al. 2010) or compound-specific stable isotopes (McMahon et al. 2016) could be used to quantify the flow of organic matter from dead corals to macroalgae in an experimental setting, or seawater from reefs with varying levels of coral mortality could be collected and used to test the responses of macroalgae.

In conclusion, this study highlights how mass coral mortality events, trigged by marine heat waves, may add additional sources of nutrients into coral reef biogeochemical cycles, which are available to opportunistic macroalgae. These changes in nutrient dynamics could have significant impacts on coral reefs, particularly if those sources are specifically becoming more available because key ecosystem engineers such as scleractinian corals are in decline (Wild et al. 2011). It also suggests that these nutrients can be retained within reefs and can have both short-term and long-term impacts on their biogeochemical cycles. Although it is not yet known how long these nutrients remain in the system, if other environmental conditions are favourable enough, then corals might still be able to recover (Graham et al. 2015). However, if these same reefs are also facing other local anthropogenic stressors, such as nutrient runoff or overfishing of herbivores, then large coral mortality events may result in competitive advantages to benthic organisms such as macroalgae, leading to a benthic regime shift (Ainsworth et al. 2019). This emphasises the critical need to manage local stressors by detecting and reducing nutrient runoff and other drivers, especially on reefs that do still have high abundance of corals, and/ or have recently bleached.

Acknowledgements We thank Seychelles Fishing Authority, Seychelles Marine Parks Authority and Jan Dajka for field and laboratory assistance in the Seychelles, Centre de Recherches Insulaires et Observatoire de l'Environnement (CRIOBE) and Service National d'Observation CORAIL data and assistance in Mo'orea, and David Hughes and Jon Crosse from Lancaster Environment Centre for extensive help with preparations for fieldwork and with the subsequent stable isotopic and elemental analyses. The project was funded via a grant from the Royal Society (RG150710).

\section{Declarations}

Conflict of interest On behalf of all authors, the corresponding author states that there is no conflict of interest.

Open Access This article is licensed under a Creative Commons Attribution 4.0 International License, which permits use, sharing, adaptation, distribution and reproduction in any medium or format, as long as you give appropriate credit to the original author(s) and the source, provide a link to the Creative Commons licence, and indicate if changes were made. The images or other third party material in this article are included in the article's Creative Commons licence, unless indicated otherwise in a credit line to the material. If material is not included in the article's Creative Commons licence and your intended use is not permitted by statutory regulation or exceeds the permitted use, you will need to obtain permission directly from the copyright 
holder. To view a copy of this licence, visit http://creativecommons. org/licenses/by/4.0/.

\section{References}

Adam TC, Burkepile DE, Holbrook SJ, Carpenter RC, Claudet J, Loiseau C, Thiault L, Schmitt RJ (2021) Landscape-scale patterns of nutrient enrichment in a coral reef ecosystem: implications for coral to algae phase shifts. Ecol Appl 31:e02227

Ainsworth TD, Hurd CL, Gates RD, Boyd PW (2019) How do we overcome abrupt degradation of marine ecosystems and meet the challenge of heat waves and climate extremes? Glob Chang Biol 26:343-354

Barott KL, Rohwer FL (2012) Unseen players shape benthic competition on coral reefs. Trends Microbiol 20:612-628

Bierwagen SL, Heupel MR, Chin A, Simpfendorfer CA (2018) Trophodynamics as a tool for understanding coral reef ecosystems. Front Mar Sci 5:24

Briand MJ, Bonnet X, Goiran C, Guillou G, Letourmeur Y (2015) Major sources of organic matter in a complex coral reef lagoon: Identification from isotopic signatures $\left(\delta^{13} \mathrm{C}\right.$ and $\left.\delta^{15} \mathrm{~N}\right)$. PLoS ONE 10:e 0131555

Brown BE, Bythell JC (2005) Perspectives on mucus secretion in reef corals. Mar Ecol Prog Ser 296:291-309

Burkepile DE, Allgeier JE, Shantz AA, Pritchard CE, Lemoine NP, Bhatti LH, Layman CA (2013) Nutrient supply from fishes facilitates macroalgae and suppresses in a Caribbean coral reef ecosystem. Sci Rep 3:1493

Burkepile DE, Shantz AA, Adam TC, Munsterman KS, Speare KE, Ladd MC, Holbrook SJ (2020) Nitrogen identity drives differential impacts of nutrients on coral bleaching and mortality. Ecosystem 23:798-811

Bythell JC, Wild C (2011) Biology and ecology of coral mucus release. J Exp Mar Biol Ecol 408:88-93

Clausing RJ, Fong P (2016) Environmental variability drives rapid and dramatic changes in nutrient limitation of tropical macroalgae with different ecological strategies. Coral Reefs 35:669-680

Coffroth MA (1990) Mucus sheet formation on poritid corals: An evaluation of coral mucus as a nutrient source on reefs. Mar Biol 105:39-49

Costanzo SD, O’Donohue MJ, Dennison WC, Loneragan N, Thomas $M$ (2001) A new approach for detecting and mapping sewage impacts. Mar Pollut Bull 42:149-156

D'Angelo C, Wiedenmann J (2014) Impacts of nutrient enrichment on coral reefs: new perspectives and implications for coastal management and reef survival. Curr Opin Environ Sustain 7:82-93

Davey M, Holmes G, Johnstone R (2008) High rates of nitrogen fixation (acetylene reduction) on coral skeletons following bleaching and mortality. Coral Reefs 27:227-236

de Goeij JM, van Oevelen D, Vermeij MJA, Osinga R, Middelburg JJ, de Goeij AFPM, Admiraal W (2013) Surviving in a marine desert: the sponge loop retains resources within coral reefs. Science 342:108-110

Diaz-Pulido G, McCook LJ (2002) The fate of bleached corals: patterns and dynamics of algal recruitment. Mar Ecol Prog Ser 232:115-128

Donovan MK, Adam TC, Shantz AA, Speare KE, Munsterman KS, Rice MM, Schmitt RJ, Holbrook SJ, Burkepile DE (2020) Nitrogen pollution interacts with heat stress to increase coral bleaching across the seascape. PNAS 117:5351-5357
Fabricius KE (2005) Effects of terrestrial runoff on the ecology of corals and coral reefs: Review and synthesis. Mar Pollut Bull 50:125-146

Ferrier-Pagès C, Gattuso J-P, Cauwet G, Jaubert J, Allemand D (1998) Release of dissolved organic carbon and nitrogen by the zooxanthellate coral Galaxea fascicularis. Mar Ecol Prog Ser 172:265-274

Fitt WK, Gates RD, Hoegh-Guldberg O, Bythell JC, Jatkar A, Grottoli AG, Gomez M, Fisher P, Lajeunesse TC, Pantos O, Iglesias-Prieto R, Franklin DJ, Rodrigues LJ, Torregiani JM (2009) Response of two species of Indo-Pacific corals, Porites cylindrica and Stylophora pistillata, to short-term thermal stress: The host does matter in determining the tolerance of corals to bleaching. J Exp Mar Biol Ecol 373:102-110

Fong P, Donohoe RM, Zedler JB (1994) Nutrient concentration in tissue of the macroalga Enteromorpha as a function of nutrient history: an experimental evaluation using field microcosms. Mar Ecol Prog Ser 106:273-281

Fulton CJ, Abesamis RA, Berström C, Depczynski M, Graham NAJ, Holmes TH, Kulbicki M, Noble MM, Radford BT, Tano S, Tinkler P, Wernberg T, Wilson SK (2019) Form and function of tropical macroalgal reefs in the Anthropocene. Funct Ecol 33:989-999

Galloway J, Dentener F, Capone DG, Boyer EW, Howarth RW, Sietzinger SP, Asner GP, Cleveland CC, Green PA, Holland EA, Karl DM, Michaels AF, Porter JH, Townsend AR, Vörösmarty CJ (2004) Nitrogen cycles: past, present, and future. Biogeochemistry 70:153-226

García-Seoane R, Aboal JR, Boquete MT, Fernández JA (2018) Biomonitoring coastal environments with transplanted macroalgae: a methodological review. Mar Pollut Bull 135:988-999

Gates RD (1990) Seawater temperature and sublethal coral bleaching in Jamaica. Coral Reefs 8:193-198

Glynn PW (1993) Coral reef bleaching: ecological perspectives. Coral Reefs 12:1-17

Graham NAJ, Jennings S, MacNeil MA, Mouillot D, Wilson SK (2015) Predicting climate-driven regime shifts versus rebound potential in coral reefs. Nature 518:1-4

Graham NAJ, Wilson SK, Carr P, Hoey AS, Jennings S, MacNeil MA (2018) Seabirds enhance coral reef productivity and functioning in absence of invasive rats. Nature 559:250-253

Haas AF, Naumann MS, Struck U, Mayr C, el-Zibdah M, Wild C (2010) Organic matter release by coral reef-associated benthic algae in the Northern Red Sea. J Exp Mar Biol Ecol 389:53-60

Haas AF, Fairoz MFM, Kelly LW, Nelson CE, Dinsdale EA, Edwards RA, Rohwer F (2016) Global microbialisation of coral reefs. Nat Microbiol 1:16042

Heaton THE (1986) Isotopic studies of nitrogen pollution in the hydrosphere and atmosphere: a review. Chem Geol Isot Geosci 59:87-102

Hédouin L, Rouzé H, Berthe C, Perez-Rosales G, Martinez E, Chancerelle Y, Galand PE, Lerouvereur F, Nugues MN, Pochon X, Siu G, Steneck R, Planes S (2020) Contrasting patterns of mortality in Polynesian coral reefs following the third global coral bleaching event in 2016. Coral Reefs. https://doi.org/10. 1007/s00338-020-01914-w

Horta e Costa B, Claudet J, Franco G, Erzini K, Caro A, Gonçalves EJ (2016) A regulation-based classification system for Marine Protected Areas (MPAs). Marine Policy 72:192-198

Hughes T, Anderson KD, Connolly SR, Heron SF, Kerry JT, Lough JM, Wilson S (2018) Spatial and temporal patterns of mass bleaching of corals in the Anthropocene. Science 359:80-83

Hughes TP, Kerry JT, Baird AH, Connolly SR, Chase TJ, Dietzel A, Hill T, Hoey AS, Hoogenboom MO, Jacobson M, Kerswell A, Madin JS, Mieog A, Paley AS, Pratchett MS, Torda G, Woods 
RM (2019) Global warming impairs stock-recruitment dynamics of corals. Nature 568:387-390

Kolasinski J, Rogers K, Cuet P, Barry B, Frouin P (2011) Sources of particulate organic matter at the ecosystem scale: a stable isotope and trace element study in a tropical coral reef. Mar Ecol Prog Ser 443:77-93

Leggat WP, Camp EF, Suggett DJ, Heron SF, Fordyce AJ, Gardner S, Deakin L, Turner M, Beeching LJ, Kuzhiumparambil U, Eakin CM (2019) Rapid coral decay is associated with marine heatwave mortality events on reefs. Curr Biol 29:2723-2730

Leichter JJ, Alldredge AL, Bernadi G, Brooks AJ, Carlson CA, Carpenter RC, Edmunds PJ, Fewings MR, Hanson KM, Hench JL, Holbrook SJ, Nelson CE, Schmitt RJ, Toonen RJ, Washburn L, Wyatt ASJ (2013) Biological and physical interactions on a tropical island coral reef: Transport and retention processes on Moorea, French Polynesia. Oceanogr 26:52-63

Lin DT, Fong P (2008) Macroalgal bioindicators (growth, tissue N, $\delta^{15} \mathrm{~N}$ ) detect nutrient enrichment from shrimp farm effluent entering Opunohu Bay, Moorea, French Polynesia. Mar Pollut Bull 56:245-249

Marconi M, Giordano M, Raven JA (2011) Impact of taxonomy, geography, and depth on $\delta^{13} \mathrm{C}$ and $\delta^{15} \mathrm{~N}$ in a large collection of macroalgae. J Phycol 47:1023-1035

McMahon KW, Thorrold SR, Houghton LA, Berumen ML (2016) Tracing carbon flow through coral reef food webs using a compound-specific stable isotope approach. Oceologia 180:809-821

Moulton OM, Altabet MA, Beman JM, Deegan LA, Lloret J, Lyons MK, Nelson JA, Pfister CA (2016) Microbial associations with macrobiota in coastal ecosystems: patterns and implications for nitrogen cycling. Front Ecol Environ 14:200-208

Mumby PJ, Steneck RS (2018) Paradigm lost: dynamic nutrients and missing detritus on coral reefs. Bioscience 68:487-495

Naumann MS, Haas AF, Struck U, Mayr C, el-Zibdah M, Wild, C, (2009) Organic matter release by dominant hermatypic corals of the Northern Red Sea. Coral Reefs 29:649-659

Naumann MS, Mayr C, Struck U, Wild C (2010) Coral mucus stable isotope composition and labelling: experimental evidence for mucus uptake by epizoic acoelomorph worms. Mar Biol 157:2521-2531

Niggl W, Glas M, Laforsch C, Mayr C, and Wild C (2009) First evidence of coral bleaching stimulating organic matter release by reef corals. In: Proceedings of 11th International Coral Reef Symposium, vol 2, pp 911-916

Pawlik JR, Burkepile DE, Thurber RV, Vega R (2016) A vicious cycle? Altered carbon and nutrient cycling may explain the low resilience of Caribbean coral reefs. Bioscience 66:470-476

Pratchett M, McCowan D, Maynard JA, Heron SF (2013) Changes in bleaching susceptibility among corals subject to ocean warming and recurrent bleaching in Moorea. French Polynesia PLoS One 8:e70443

R Core Team (2018) R: A language and environment for statistical computing. R Foundation for Statistical Computing, Vienna, Austria. URL https://www.R-project.org/

Radice VZ, Fry B, Dove SG, Hoegh-Guldberg O (2020) Biogeochemical variability and trophic status of reef water column following a coral bleaching event. Coral Reefs. https://doi.org/ 10.1007/s00338-020-02021-6

Rix L, De Goeij JM, Mueller CE, Struck U, Middelburg JJ, Van Duyl FC, Van Oevelen D (2016) Coral mucus fuels the sponge loop in warm-and cold-water coral reef ecosystems. Sci Rep 6:1-11
Rix L, de Goeij JM, van Oevelen D, Struck U, Al-Horani FA, Wild C, Naumann MS (2017) Differential recycling of coral and algal dissolved organic matter via the sponge loop. Funct Ecol 31:778-789

Ryan JA and Ulrich JM (2020) xts: eXtensible Time Series. R package version $0.12-0$. https://CRAN.R-project.org/package= xts

Schaffelke B (2002) Particulate organic matter as an alternative nutrient source for tropical Sargassum species (Fucules, Phaeophyceae). J Phycol 35:1150-1157

Schaffelke B, Klumpp DW (1998) Nutrient-limited growth of the coral reef macroalgae Sargassum baccularia and experimental growth enhancement by nutrient addition in continuous flow culture. Mar Ecol Prog Ser 164:199-211

Tanaka Y, Nakajima R (2018) Dissolved organic matter in coral reefs: distribution, production, and bacterial consumption. In: Iguchi A, Hongo C (eds) Coral Reef Studies of Japan: Coral Reefs of the World, vol 13. Springer, Singapore, pp 7-27

Tanaka Y, Ogawa H, Miyajima T (2010) Effects of nutrient enrichment on the release of DOC and DON by scleractinian coral Montipora digitata. Coral Reefs 29:675-682

Tsounis G and Edmunds PJ (2016) The potential for self-seeding by the coral Pocillopora spp. in Moorea, French Polynesia. PeerJ 4: e2544

Vercelloni J, Kayal M, Chancerelle Y, Planes S (2019) Exposure, vulnerability, and resiliency of French Polynesian coral reefs to environmental disturbances. Sci Rep 9:1027

Wild C, Huettel M, Klueter A, Kremb A, Rasheed MYM, BoB J (2004a) Coral mucus functions as an energy carrier and particle trap in the reef ecosystem. Nature 428:66-70

Wild C, Rasheed M, Werner U, Franke U, Johnstone R, Huettel M (2004b) Degradation and mineralisation of coral mucus in reef environments. Mar Ecol Prog Ser 267:159-171

Wild C, Niggl W, Naumann MS, Haas AF (2010) Organic matter release by Red Sea coral reef organisms-potential effects on microbial activity and in situ $\mathrm{O}_{2}$ availability. Mar Ecol Prog Ser 411:61-71

Wild C, Hoegh-Guldberg O, Naumann MS, Colombo-Pallotta MF, Ateweberhan M, Fitt WK, Iglesias-Prieto R, Palmer C, Bythell JC, Ortiz J-C, Loya Y, van Woesik R (2011) Climate change impedes scleractinian corals as primary reef ecosystem engineers. Mar Fresh Res 62:205-215

Williams GJ, Sandin SA, Zgliczynski BJ, Fox MD, Gove JM, Rogers JS, Furby JS, Hartmann AC, Caldwell ZR, Price NN, Smith JE (2018) Biophysical drivers of coral trophic depth zonation. Mar Biol 165:1-15

Wilson SK, Robinson JPW, Chong-Seng K, Robinson J, Graham NAJ (2019) Boom and bust of keystone structure on coral reefs. Coral Reefs 38:625-635

Wooldridge SA (2009) A new conceptual model for the enhanced release of mucus in symbiotic reef corals during "bleaching" conditions. Mar Ecol Prog Ser 396:145-152

Wyatt ASJ, Lowe RJ, Humphries S, Waite AM (2013) Particulate nutrient fluxes over a fringing coral reef from carbon to nitrogen ratios and stable isotopes. Limnol Oceanogr 58:409-427

Zeileis A, Grothendieck G (2005) zoo: S3 Infrastructure for Regular and Irregular Time Series. J Stat Softw 14(6):1-27. https://doi. org/10.18637/jss.v014.i06.

Publisher's Note Springer Nature remains neutral with regard to jurisdictional claims in published maps and institutional affiliations. 